\title{
The concept of Lomaya and Pilohayanga weir rehabilitation based on technical and economic aspects
}

\author{
Ninik Khorida ${ }^{1, *}$, Mamok Suprapto ${ }^{2}$, and Syafi ' ${ }^{2}$ \\ ${ }^{1}$ Student of Master Program of Civil Engineering, Universitas Sebelas Maret, Surakarta, Indonesia \\ ${ }^{2}$ Lecturer of Master Program of Civil Engineering, Universitas Sebelas Maret, Surakarta, Indonesia
}

\begin{abstract}
Lomaya and Pilohayanga Weirs are located in Limboto-BoneBolango River, Bone Bolango District, and Gorontalo Province. Pilohayanga Weir is located at 1,500 meters downstream of Lomaya Weir, it has 1,045 hectares of irrigation services area while also serving as a supplier of raw water requirements. The damage that occurred in Pilohayanga Weir resulted in its decreasing function, and also resulted in unmet irrigation and raw water needs. Meanwhile, Lomaya Weir has 3,148 hectares of irrigation services area. The aim of this research is to find the optimal solution among several alternative design concepts to meet Pilohayanga Weir's water needs by supplying water from Lomaya Weir, considering both the technical aspects of hydraulic and the cost of implementation which must be within the economical boundary. In conclusion, the exact solution required is by the addition of several designs, these include: a) creating a new intake area on the right side of Pilohayanga Weir; b) creating an additional channel, flushing out sediment from Lomaya Weir; c) creating sand trap; and d) creating a carrier which will be channelled to Pilohayanga Irrigation Area.
\end{abstract}

\section{Introduction}

Weirs may be classified according to the broad function they serve. These functions include water storage, water diversion, and water retention [1]. A weir is a water structure that is built across a river or river channel to primarily raise the water level so that river water can be trapped, thereby allowing it to flow by gravity into the area in need of water [2]. The main components of a weir are the weir body, intake, flushing buildings, and complementary buildings $[3,4,5]$.

The destruction that had occurred in this weir resulted in its inability to function as a supplier of irrigation water for farming and also rendered it unable to meet daily domestic water needs as this is currently declining, this resulted in many agricultural lands being converted into residential areas. Therefore, to remedy the situation, an alternative design is needed for the provision of irrigation water for farming and also the provision of daily domestic water needs in Pilohayanga irrigation area.

* Corresponding author: nayla.ninik@gmail.com, ninikkhorida@yahoo.com 
Therefore, the purpose of this research is to enable the selection of the appropriate design from several alternatives, so as to support irrigation infrastructure services in Pilohayanga irrigation area. The objective of this research work is to obtain the optimal design concept which would be implemented using hydraulic engineering principles and within economical limits so as to be able to support agricultural production and daily domestic water needs.

\section{Theory and methodology}

\subsection{Theory}

The primary function of weirs is to raise and maintain the minimum flow of water upstream in order to meet the water requirements for irrigation. In view of this, the presence of leaks in weirs makes it unable to meet the minimum water surface requirement [3]. Water obtained from the river must also be able to flow with little sedimentation. This is because the presence of relatively high sedimentation in the water will interrupt the amount of water flowing into the channel. Therefore, water-borne sediments are minimized by constructing sand trap as sediments flusher.

To repair the weir so as to still maintain the amount of water that flows into the channel, it is required that the height difference is maintained so as to ensure that the minimum water requirement in the irrigation area is met, hence the flow of water by gravity is still sustained.

\subsection{Hydraulic technical analysis}

Technical analysis, in this case, refers to the hydraulic analysis which aims to determine the elevation of the water level and the height difference, as well as the basic design of the complementary building which includes: intake and sandtrap buildings, the syphon, and the carrier channel to the Pilohayanga irrigation area [6]. The determination of the elevation and height difference in the supplementary buildings is to ensure that water flows to the Pilohayanga irrigation area,

Also, the economic analysis aims to determine the costs which will be incurred from each design alternatives, this will, therefore, enable proper planning and execution.

\subsubsection{Hydraulic analysis of the intake}

In accordance with its purpose as the main building for the supply of irrigation water, the weir is equipped with an intake building which is also equipped with a door. The door has the capacity to take at least $120 \%$ of the intake water requirement [7]. The speed at which water enters is between $(1.00-2.00) \mathrm{m} / \mathrm{second}[8]$.

$$
\begin{aligned}
& Q p=\mu b h i \sqrt{ }(2 g z) \\
& h i=Q p / \mu b \sqrt{ }(2 g z)
\end{aligned}
$$

\subsubsection{Hydraulic analysis of the sand trap}

The sand trap functions as a building for collecting a deposit of particles with diameters $>$ $0.06-0.07 \mathrm{~mm}$ and other fine particles to avoid entering the irrigation network [9]. The sand trap is usually placed in the downstream of the intake $(\mathrm{L} / \mathrm{B}>8.00)$, to prevent the flow 
from "meander" into the bag [4]. The sand trap is equipped with a rinsing door that is used to drain the sediment when the sand trap is fully loaded. The dimensions of the sand trap can be planned based on the formula highlighted below:

$$
L B=Q / W
$$

\subsubsection{Syphon hydraulic analysis}

Syphon hydraulic planning should consider reducing energy loss. In this case, it is the energy loss caused by friction factor, bend, switch, and filter factor (trashrack). To reduce energy losses, the location of the plan is cultivated in the shortest span, while also minimizing the number of turns in its construction.

Minimum syphon diameter $\geq 0.60 \mathrm{~m}$, this is to allow cleaning and inspection [10]. To avoid the blockage caused by incoming garbage, the mouth of the pipeline is protected by a trash rack. Also, the flow rate in the syphon should not be less than $1 \mathrm{~m} / \mathrm{sec}$ to prevent sedimentation.

\subsubsection{Channel carrier to Pilohayanga irrigation area}

The channel plan debit is calculated using the formula:

$$
Q=A \times a
$$

The calculation of water requirements is based on certain factors, this includes land preparation, water requirement for plants, percolation and seepage, change of water layer, effective rainfall, cropping pattern and mainstay discharge. Also, the consideration of the energy loss in the irrigation networks is important as well as the channel flow which is regarded as a steady flow.

\subsubsection{Estimated budget cost plan}

The preparation of the Budget Plan for the construction work is based on the price of the materials and wages applicable at the job site. This is usually obtained from the Technical Information Center for Building, information from the Ministry of Public Works and also real wage surveys in the field. Labour wages should refer to the "Minimum Wage Regional" issued by the Minister of Manpower and the Governor.

\subsection{Methodology}

\subsubsection{Location}

The Lomaya and Pilohayanga weir are located on the Bone-Bolango River. Administratively, the Bone Bolango River is located in Bone Bolango District, Gorontalo Province. Both the Lomaya and Pilohayanga Weirs are in the Bolango river which is one of the largest rivers in Gorontalo Province.

The weir in the upstream which is the Lomaya Weir has a left intake with the purpose of fulfilling the water requirement of the Lomaya irrigation area which has an area of 3,148 hectares. While the Pilohayanga Weir is located at 1,500 meters, downstream of the Lomaya Weir. It was built in 1982 and has a right intake with the purpose of fulfilling the irrigation needs in the Pilohayanga irrigated areas with an area of 1,045 hectares. Pilohayanga Weir also serves as a supplier of daily domestic water needs. 
To reach the location of research, the use of four-wheeled vehicle or two-wheel within the paved road is applicable, this is because the road condition is still relatively good and it is within a distance of \pm 15 minutes from the city of Gorontalo, which is the capital of Gorontalo Province. The Lomaya Weir is located within the coordinates of X: 509197.07; and Y: 69458.08, while the coordinates of the Pilohayanga Weir is X: 508193.47; Y: 68457.34 .

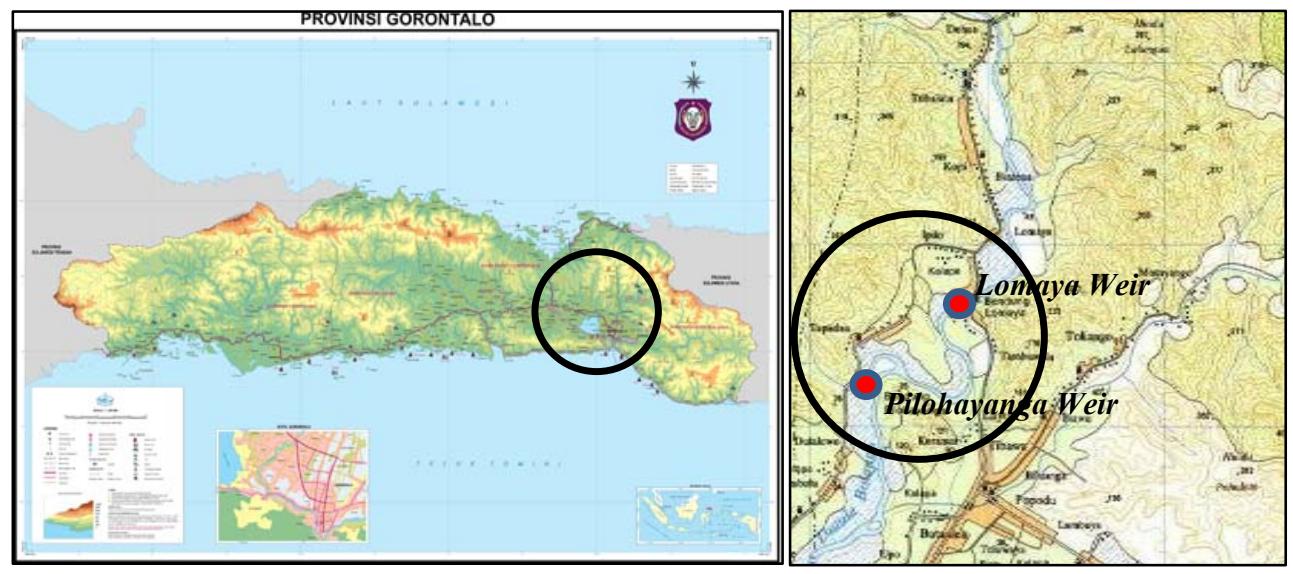

Fig. 1. Location of Lomaya and Pilohayanga Weirs.

\subsubsection{Data collection and analysis}

This research requires data, such as The Earth Map with the scale of 1:25,000, location situation map of Lomaya and Pilohayanga Weirs, material price, wage and tool price, topographic analysis, and hydrology analysis data (flood data, cropping pattern and irrigation area).

The data analysis begins by determining: a) alternative basic design concepts to ensure water supply in Pilohayanga; b) hydraulic technical analysis; c) Budget Cost Plan analysis; and d) selection of optimal solutions alternative design concepts.

\section{Discussion}

\subsection{Alternative design concepts}

Several alternative designs were arranged to supply the water needs of Pilohayanga irrigation area. The first alternative is the situation where the water supply for Pilohayanga is taken from the left intake of the existing Lomaya Weir.

This first alternative needed several designs, these include: a) the addition of the left intake door, 1 piece with the width of 1.50 meters which is then followed by widening the sand trap by 9.00 meters; b) carrier channeling to the syphon along \pm 300 meters; c) construction of new syphons which crosses over the Bolango River; c) making of a carrier channel to the Pilohayanga Irrigation Area of $\pm 1,000$ meters. The calculations of the technical hydraulics also consider the loss of energy in each complementary building, so that water can be ascertained to the location of the Pilohayanga irrigation area. 

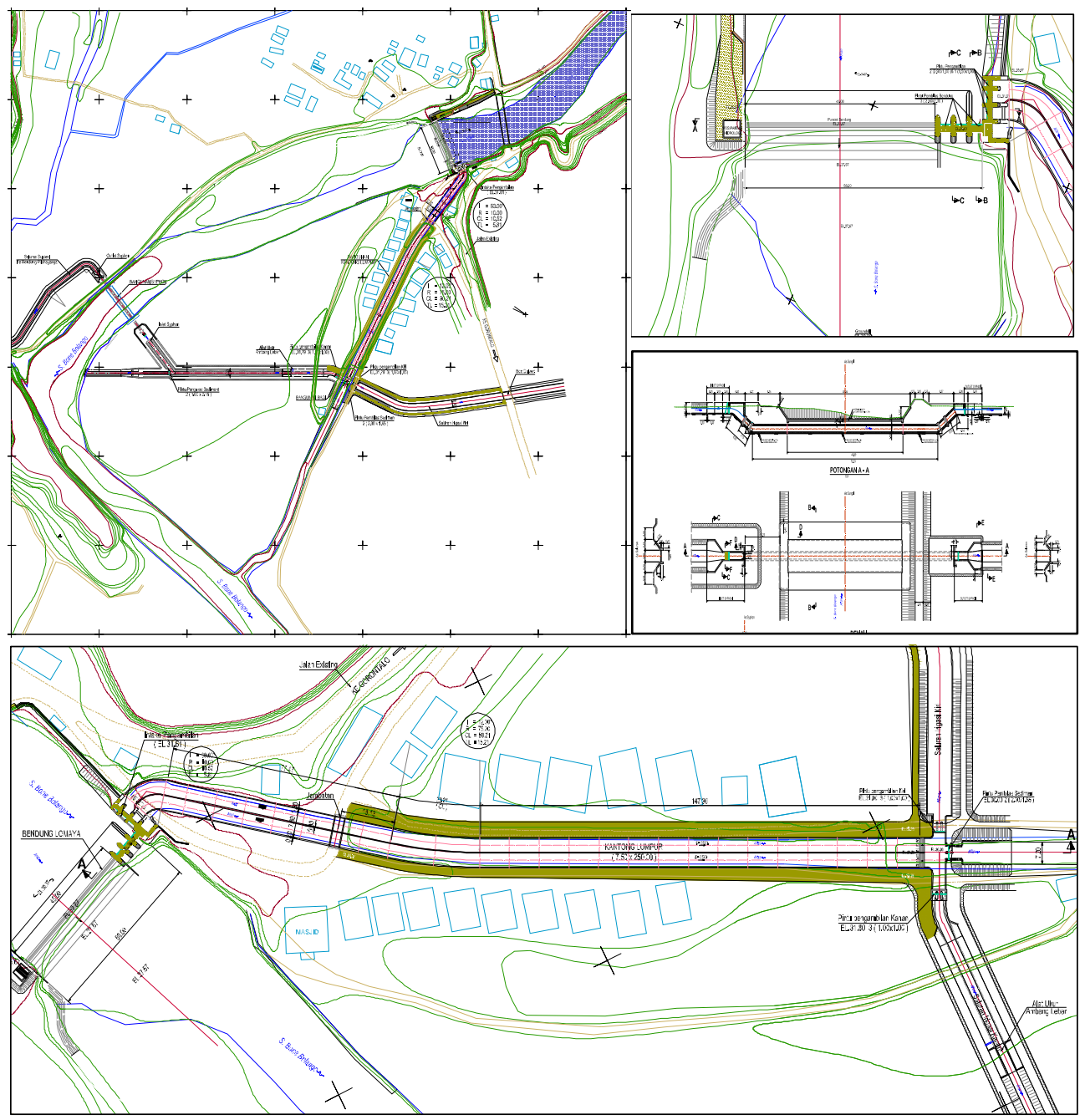

Fig. 2. The layout of the first alternative.

The second alternative involves the making of a right intake at Lomaya Weir. The water supply to Pilohayanga irrigation area is then distributed through the right channel of the river. The second alternative also needed several designs. Such as a) making of a new intake area in the right side with two 2 doors; b) the addition of channel flushing sediment at Lomaya Weir; c) making of the sand trap, and d) making of a carrier channel to Pilohayanga irrigation area along $\pm 1,400$ meters. 